\title{
Education amidst COVID-19 Disruption: Perceived Difficulty in Implementing Flexible Learning Strategies of Teacher Education Faculty Members in a State University
}

\author{
Kevin T. Lagat \\ Biliran Province State University, Biliran, Philippines
}

\begin{tabular}{l} 
Article history: \\
Submitted: 27 October 2020 \\
Revised: 13 December 2020 \\
Accepted: 31 December 2020 \\
\hline Keywords: \\
Education \\
COVID-19 \\
Flexible learning \\
Teacher education \\
Descriptive-correlational \\
State University \\
Philippines
\end{tabular}

ABSTRACT. This descriptive-correlational study described and analyzed the perceived difficulty in implementing Flexible Learning (FL) strategies of 60 teacher education faculty members of a state university in an eastern province in the Philippines. Moreover, this study investigated the correlation between the faculty members' demographics and their perceived difficulty in implementing flexible learning strategies. Data were collected using a researcher-made questionnaire and analyzed using weighted mean, standard deviation, Spearman Rho Correlation, and Rank-Biserial Correlation. Results revealed that faculty members, in general, considered flexible learning strategies to be slightly difficult to implement. A significant relationship was also found between the faculty members' generational age and their perceived difficulty in the Instructional Approach and Resources domain. The findings of this study suggest capacity building initiatives to address the identified difficult flexible learning strategies of the faculty members.

\subsection{Introduction}

The outbreak of the global coronavirus disease (COVID-19) pandemic has brought unexpected and unprecedented disruptions in the lives of many people. To contain the rapid transmission of the virus, countries all over the world have implemented health protocols, including border lockdowns, and other social restrictions, that in turn resulted in negative repercussions on many economic activities (Akbulev, Ilkin, \& Aliyey, 2020; Arora, 2020; Atalan, 2020; Quina \& Wen, 2020). In the Philippines alone, the unemployment rate rose to 17.7 percent accounting for 7.3 million unemployed Filipinos in the labor force in April 2020 (Philippine Statistics Authority, 2020). It was also projected that the country would lose 2.0 trillion pesos or about 9.4 percent of its Gross Domestic Product (GDP) by the end of the year (National Economic and Development Authority, 2020). This is aside from the projected decline in remittance inflow of the country by $23-32 \%$ and household spending per capita by 2.2-3.3\% (Murakami, Shimizutani, \& Yamada, 2020).

Aside from the health and economic impact of COVID-19, it has also shut down institutions such as schools and universities across the world (Jæger \& Blaabæk, 2020). The worldwide closure of schools was recorded to have affected $90 \%$ of the world's student population (UNESCO, 2020). In the Philippines, upon the recommendation of the Inter-Agency Task Force on Emerging Infectious Diseases (IATF), classes have been suspended at all levels since March 2020 when the Department of Health $(\mathrm{DOH})$ confirmed the first recorded COVID-19 cases to avoid the transmission of the virus in schools. This prompted higher education institutions to implement necessary countermeasures and policies to facilitate teaching and learning amidst the pandemic to finish the school year. This includes online submission of requirements, remedial instructions, and pass-all policy, etc. (Toquero, 2020).

Education must continue, and learning must not stop since the closure of schools has negative consequences on the safety, protection, well-being of students, and learning equality (Jæger \& Blaabæk, 2020). However, the reopening of schools amidst the pandemic must not compromise the health and safety of the students and school personnel as the primordial concern at the moment (UNESCO, 2020). To do this, the framework for reopening schools by UNESCO suggests that governments and schools must invest in remote learning modalities and apply alternative academic calendars, among others. In contrast, the threat of virus transmission in schools is still imminent (UNESCO, 2020). Thus, the Commission on Higher Education (CHED) is eyeing to transition the learning modality from face-to-face to Flexible Learning (FL) come the opening of the next school year while restrictions on the former are still in effect (Cervantes, 2020).

Flexible Learning (FL) grew out from the demand for a more diversified, more open, and more student-centered higher education in the 1990s to cater to the needs of the students (Steepless, Goodyear, \& Mellar, 1994; Alexander, 2010; Gillett-Swan, 2017; Huang, Liu, Tlili, Yang, \& Wang, 2020). 
FL has been defined as a learner-centered pedagogy that provides teachers and learners a balance of power in choosing how teaching and learning are carried out to fit the individual contexts and preferences of the students (Huang, Liu, Tlili, Yang, \& Wang, 2020; Joan, 2013; Alexander, 2010). It is a pedagogical approach that allows flexibility in pace, place, audience, and path of learning by integrating technologies (Cassidy, Fu, Valley, Lomas, \& Jovel, 2016; Alder, Müller, Stahl, \& Müller, 2018). Moreover, this pedagogy is anchored on the constructivism educational philosophy, which recognizes learners' ability to construct new meaning or knowledge based on prior experiences and believes that learning takes place when learners are actively involved in the learning process (Casey \& Wilson, 2005; Elliott, Kratochwill, Littlefield Cook, \& Travers, 2000).

FL focuses on learner-directed control over institutional requirements. In other words, students choose their mode of study like time and location at which they study, and the mode of learning delivery, e.g., text or printed, video or online using internet, etc., and the mode of assessment thus, widening access to higher education (Alexander, 2010; Herat, 2000). Hence, in this pedagogy, learners assume the responsibility of their learning, which is in a traditional setting the teachers' responsibility (Lewis \& Spencer, 1986; Goode, Willis, Wolf, \& Harris, 2007). Collis and Moonen (2002) identified five dimensions where flexibility can be implemented: (a.) Time, (b.) Content, (c.) Entry Requirements, (d.) Instructional approach and resources, (e.) Delivery and Logistics.

Time refers to the duration for starting and finishing the course, the schedule for submission of course requirements and assessments, the pace of studying the course, and length of participation in learning activities (Collis \& Moonen, 2002; Casey \& Wilson, 2005; Alder, Müller, Stahl, \& Müller, 2018). Technically, this dimension asks when and where learning occurs (Huang, Liu, Tlili, Yang, \& Wang, 2020; Alexander, 2010). Content, on the one hand, refers to the topics of the course, its sequence, size, scope, the form of orientation, key learning materials, and assessment (Collis \& Moonen, 2002; Alder, Müller, Stahl, \& Müller, 2018) while entry requirements refer to the conditions for participation in the course (Collis \& Moonen, 2002). Moreover, the instructional approach and resources refer to how learning activities are carried out, e.g., face-to-face, group, individual, and the language used for instruction (Collis \& Moonen, 2002; Alder, Müller, Stahl, \& Müller, 2018). It also refers to the way students can access the learning materials (Huang, Liu, Tlili, Yang, \& Wang, 2020). Lastly, delivery and logistics refer to the availability of student support from instructors or tutors in accomplishing the course and the way or mode by which such support can be obtained, e.g., through online meetings or real-time chatting tools, etc. (Collis \& Moonen, 2002; Huang, Liu, Tlili, Yang, \& Wang, 2020).

Much has been said regarding the effectiveness of $\mathrm{FL}$ in facilitating teaching and learning, promoting quality education, fostering innovativeness of teachers, improving learners' achievement and engagement, and its usefulness for more open and inclusive education (Lewis et al., 2016; Joan, 2013; Dorrian \& Wache, 2008; Steeples, Goodyear, \& Mellar, 1994; Alder, Müller, Stahl, \& Müller, 2018). But little is known about the specific flexible learning strategies that teachers perceive to be more difficult to implement in teaching and learning management level identified by Casey and Wilson (2005), especially in this time of pandemic and in a developing country like the Philippines (Sheriffdeen, 2007)

In this context, this paper described and analyzed the perceived difficulty in implementing Flexible Learning (FL) strategies of teacher education faculty members of Biliran Province State University. Moreover, this paper also sought to determine whether a significant relationship exists between the faculty members' perceived difficulty and their demographics, such as age, sex, and educational background. The findings of this study will be useful for identifying the needs of the teachers and in designing teacher training programs to capacitate them in implementing $\mathrm{FL}$ in their classes.

\subsection{Framework of the Study}

This study is chiefly anchored on the theory of planned behavior, which is intended to explain self-controlled behaviors (Ajzen, 1985). It postulates that behavioral intentions can be predicted accurately based on the attitude on the behavior, subjective norm, and perceived behavioral control (Ajzen, 1991). Moreover, it posits that actual behavior can be determined by the intentions and perceived behavioral control (Ajzen, 1991). Perceived behavioral control has two main variables, perceived control and perceived difficulty (Conner, Finlay, Sheeran, \& Trafimow, 2002). Among these two variables, the perceived difficulty, which is defined as people's perception of ease or difficulty of performing the behavior, was considered as a potent predictor of behavioral intentions and behavioral achievement (Kim, 2008; Conner, Finlay, Sheeran, \& Trafimow, 2002; Ajzen, 1991). 
Literature review reveals that perceived difficulty affects both the individuals' perceived competence to perform and subsequently their engagement to a particular task (Patalla, Hooperb, Vasquezb, Pituchb, \& Steingutc, 2018). Additionally, the results of several studies have also shown that perceived difficulty has influenced the actual performance of an individual in performing a task (Kim, 2008; Conner, Finlay, Sheeran, \& Trafimow, 2002). Therefore, this theory can predict teachers' engagement or actual practices in implementing $\mathrm{FL}$ as a teaching-learning pedagogy by assessing their perceived difficulty.

\subsection{Methods}

This study utilized a quantitative research design using descriptive and correlational approaches. The descriptive approach described the perceived difficulty of faculty members in implementing FL. In contrast, the correlational approach identified the relationship between the faculty members' demographics and their perceived difficulty implementing FL. The respondents of this study were 60 faculty members comprising $76 \%$ of the whole population faculty members of the School of Teacher Education (STEd) of Biliran Province State University selected using purposive sampling design wherein the primary consideration was their affiliation to STEd.

Table 1. Profile of respondents

\begin{tabular}{lcc}
\hline Variables & $\mathrm{N}$ & $\%$ \\
\hline Generational Age & & \\
Generation Y (16-36 years old) & 29 & 48.33 \\
Generation X (37-52 years old) & 23 & 38.33 \\
Baby Boomers (53-71 years old) & 8 & 13.33 \\
Sex & & \\
Male & 28 & 46.47 \\
Female & 32 & 53.33 \\
Highest Educational Attainment & & \\
\hline Bachelor's Degree & 22 & 36.67 \\
Master's Degree & 28 & 46.67 \\
$\quad$ Doctorate Degree & 10 & 16.67 \\
Total & 60 & 100 \\
\hline
\end{tabular}

Based on the literature review, a researcher-made survey-questionnaire was made to gather the needed data. The questionnaire was divided into two parts: part I identified the demographics of the respondents, such as their generational age, sex, and highest educational attainment, while part II assessed their perceived difficulty in implementing FL strategies. The perceived difficulty questionnaire included 20 flexible teaching-learning strategies identified based on the literature review and divided into five dimensions of Flexibility by (Collis \& Moonen, 2002): (a) Time, (b) Content, (c) Entry Requirements, (d) Instructional approach and resources, (e) Delivery and Logistics. Teachers answered using a 5-point Likert scale (1=very easy, $2=$ easy, $3=$ slightly difficult, $4=$ difficult, $5=$ very difficult).

The survey-questionnaire has undergone validity and reliability testing. The validity of the questionnaire was assessed by an education researcher, a professor in professional education, and a university psychometrician using the Good and Scates Jury Validation Form, which yielded a mean score of 3.78, which imports the validity of the questionnaire. The reliability of the questionnaire, on the other hand, was tested by conducting a pilot test on 30 faculty members, some of whom were from other state universities in region VIII, who were not part of the final respondents of the 
study. The reliability index of the questionnaire yielded 0.89 using Cronbach Alpha, which ensures the questionnaire's reliability.

Moreover, the gathering of data on this study was systematic because institutional guidelines and procedures in conducting research were followed. The confidentiality of the data was also observed. Institutional review and approval and informed consent were requested and secured first before the commencement of this study. Following the approval, data were gathered. All the participants of this study were informed in writing on the nature and purpose of this study through a google form where the questionnaire was attached. Responses were collected by sending the google form to Facebook messenger and email of the respondents due to restrictions on face-to-face meetings. The researcher alone had access to the responses of the respondents.

Descriptive and Inferential statistics such as weighted mean, standard deviation, Spearman Rho Correlation, and Rank-Biserial Correlation were used to treat or analyze the data.

\subsection{Results and Discussion}

\section{Level of difficulty in five domains}

The means and standard deviations of the five domains presented in table 2 show that, in general, all the flexible learning strategies were perceived by the faculty members to be slightly difficult to implement $(M=3.31 ; S D=.87)$. This means that faculty members of the school of teacher education perceive that the implementation of flexible learning strategies classified in 5 domains will be not so difficult for them. Thus, the faculty members see a minimal problem in implementing flexible learning in their classes. Among the five domains, the entry requirement $(M=3.65 ; S D=.76)$, which concerns catering to students regardless of their lack of pre-requisite knowledge, was considered the most difficult domain. This denotes that STEd faculty members consider personalization of learning to have the highest level of difficulty among the five domains. Personalization of learning was pointed out to be one of the challenges in curriculum design in flexible learning (Géring \& Király, 2020; GillettSwan, 2017; Alexander, 2010).

The second most difficult domain was content $(M=3.44 ; S D=.79)$. This denotes that of the five domains, the flexibility in the scope and structure of the topics and assessment of the course was considered by the faculty members to be the second in terms of difficulty in implementation. This conforms to the report of Géring and Király (2020), which elucidated that the transition from the traditional framework of organizing content and assessment to a more flexible one is difficult because the faculty members are more emotionally attached to the former thus, preventing flexibility. Alder et al. (2018) also noted that planning, organizing, and reflecting on individual learning is one of the difficulties in flexible learning.

The Third domain considered slightly difficult or with a moderate level of difficulty was Time $(\mathrm{M}=3.31 ; \mathrm{SD}=0.83)$ and Instructional Approach and Resources $(\mathrm{M}=3.31 ; \mathrm{SD}=0.86)$. This denotes that faculty members find the strategies relating to the pace, place, and strategies of learning processes like group or individual activities in a flexible setting to be slightly difficult or moderately difficult. Finally, strategies under the Delivery and Logistics $(M=3.03$; $S D=0.98)$ were generally considered slightly difficult or moderately difficult to implement. This domain refers to the use of electronic devices for communication and the availability and delivery of needed support. This implies that faculty members do not have much trouble using electronic communication devices such as phones and computers to communicate with their students.

Table 2. Level of perceived difficulty of the five domains

\begin{tabular}{lccl}
\hline \multicolumn{1}{c}{ Domains } & Mean & SD & Interpretation \\
\hline Time & 3.31 & 0.83 & Slightly Difficult \\
Content & 3.44 & 0.79 & Difficult \\
Entry Requirement & 3.65 & 0.76 & Difficult \\
Instructional Approach and Resources & 3.31 & 0.86 & Slightly Difficult \\
Delivery and Logistics & 3.03 & 0.98 & Slightly Difficult \\
As a Whole & 3.31 & 0.87 & Slightly Difficult \\
\hline
\end{tabular}


To highlight the most difficult strategies or the flexible learning strategies with the highest level of difficulty, Table 3 presents the means and standard deviations of the top five most difficult items on flexible learning strategies. The item with the highest level of difficulty is item number 10, Catering to students regardless of their lack of pre-requisite knowledge $(M=3.65 ; S D=0.76)$.

Table 3. Activities with greater difficulty assigned

\begin{tabular}{lccc}
\multicolumn{1}{c}{ Domains } & Mean & SD & Interpretation \\
\hline $\begin{array}{l}\text { 1. Catering to students regardless of their lack } \\
\text { of pre-requisite knowledge. }\end{array}$ & 3.65 & 0.76 & Difficult \\
$\begin{array}{l}\text { 2. Enabling students to experience the course } \\
\text { in campus-based learning, web-based } \\
\text { learning, or both via different technologies, } \\
\text { such as Augmented Reality (AR). }\end{array}$ & 3.57 & 0.72 & Difficult \\
$\begin{array}{l}\text { 3. Use of a range of media formats, such as } \\
\text { podcasts, narrated screen capture, and the } \\
\text { full video of lectures. }\end{array}$ & 3.53 & 0.79 & Difficult \\
$\begin{array}{l}\text { 4. Using flexible channels of assessment } \\
\text { such as computer-based tests (e.g., online } \\
\text { test, adaptive test) and human-managed } \\
\text { assessment (paper-based test), etc. }\end{array}$ & 3.48 & 0.85 & Difficult \\
$\begin{array}{l}\text { 5. Use of Open Educational Resource (OER) } \\
\text { such as interactive mini-lessons and } \\
\text { simulations, Digital textbooks, etc. }\end{array}$ & 3.43 & 0.93 & Difficult \\
\hline
\end{tabular}

The analysis of the data presented in Table 3 indicates that flexible learning practices or strategies with the highest level of perceived difficulty involve the use of technology-mediated instruction and online learning applications or learning tools. A study and a report on the challenges of flexible learning mentioned that although these online applications are already available, some of them are very expensive to be accessed; thus, it cannot be denied that their use in Higher Education Institutions is not common (Géring \& Király, 2020; Sheriffdeen, 2007). Also, as Jansen and Merwe (2015) pointed out, some teachers sometimes have limited use of technology and are not interested in using social media tools because they are used to the traditional mode of teaching. In addition, the very limited Information Technology (IT) infrastructure and low internet connectivity can also be a reason why the faculty members perceived that the use of these tools could be very difficult to implement. Nevertheless, there is a need to capacitate the faculty members in this particular aspect to actively support the online learning of the students (Saalman, 2008).

Moreover, as shown in Table 4, male faculty members have assigned greater difficulty in implementing flexible learning strategies under the five domains $(M=3.37 ; S D=0.66)$ than female faculty members $(M=3.26 ; S D=0.88)$. For males, 3 domains were considered to be difficult namely; Entry requirement $(M=3.68 ; S D=0.67)$, Content $(M=3.43 ; S D=.79)$, and Time $(M=3.42 ; S D=0.75)$. Female faculty members on the other hand considered only two domains to be difficult; Entry requirement $(M=3.63 ; S D=0.83)$, and Content $(M=3.45 ; S D=0.80)$. Nevertheless, both groups considered all the domains to be slightly difficult. This result indicates that male faculty members need more capacity building training on flexible strategies that address the pace and place of the learning process, personalization of learning, and designing flexible content and assessments.

Table 5 reveals that when faculty members are grouped according to their generational age, faculty members under Generation $Y$ have only 1 difficult domain which is the Entry Requirement $(M=3.62 ; S D=0.82)$, Generation $Y$ faculty members have 3 difficult domains Entry requirement $(M=3.61 ; S D=0.58)$, Content $(M=3.47 ; S D=0.69)$, and Time $(M=3.42 ; S D=0.77)$, while Baby Boomers faculty members have considered 4 domains to be difficult; Entry requirement $(M=3.88 ; S D=0.99)$, Content $(M=3.71 ; S D=0.90)$, Instructional Approach and Resources $(M=3.67 ; S D=0.93)$ and Time $(\mathrm{M}=3.54 ; \mathrm{SD}=0.78)$. 
Table 4. Level of the perceived difficulty of flexible learning strategies according to sex

\begin{tabular}{lcccccc}
\hline \multirow{2}{*}{ Domains } & \multicolumn{4}{c}{ Male } & \multicolumn{2}{c}{ Female } \\
\cline { 2 - 7 } & $\mathbf{M}$ & SD & Interpretation & $\mathbf{M}$ & SD & Interpretation \\
\hline Time & 3.42 & 0.75 & Difficult & 3.22 & 0.90 & Slightly Difficult \\
Content & 3.43 & 0.79 & Difficult & 3.45 & 0.80 & Difficult \\
Entry Requirement & 3.68 & 0.67 & Difficult & 3.63 & 0.83 & Difficult \\
Instructional Approach and & 3.39 & 0.88 & Slightly Difficult & 3.23 & 0.83 & Slightly Difficult \\
Resources & & & & & & \\
Delivery and Logistics & 3.12 & 1.00 & Slightly Difficult & 2.95 & 0.95 & Slightly Difficult \\
As a Whole & 3.37 & 0.86 & Slightly Difficult & 3.26 & 0.88 & Slightly Difficult \\
\hline
\end{tabular}

Table 5. Level of the perceived difficulty of flexible learning strategies according to generational age

\begin{tabular}{lcccccccccc}
\hline \multirow{2}{*}{ Domains } & \multicolumn{3}{c}{ Generation } & \multicolumn{4}{c}{ Generation X } & \multicolumn{4}{c}{ Baby Boomers } \\
& M & SD & Int & $\mathbf{M}$ & SD & Int & M & SD & Int \\
\hline Time & 3.16 & 0.87 & SD & 3.42 & 0.77 & D & 3.54 & 0.78 & D \\
Content & 3.34 & 0.83 & SD & 3.47 & 0.69 & D & 3.71 & 0.90 & D \\
Entry Requirement & 3.62 & 0.82 & D & 3.61 & 0.58 & D & 3.88 & 0.99 & D \\
Instructional Approach \& Res. & 3.24 & 0.91 & SD & 3.27 & 0.74 & SD & 3.67 & 0.93 & D \\
Delivery and Logistics & 2.91 & 0.97 & SD & 3.11 & 0.93 & SD & 3.19 & 1.09 & SD \\
As a Whole & 3.21 & 0.91 & SD & 3.34 & 0.78 & SD & 3.58 & 0.95 & D \\
\hline
\end{tabular}

Note: $\mathrm{VE}=$ Very Easy, $\mathrm{E}=$ Easy, $\mathrm{SD}=$ Slightly Difficult, $\mathrm{D}=$ Difficult, $\mathrm{VD}=$ Very Difficult

Moreover, among the three groups, it is evident that Baby Boomers faculty members have considered all the domains to be difficult in general $(M=3.58 ; S D=.95)$. This result implies that faculty members of advanced age find it difficult to adjust to a flexible learning environment. This conforms to some previous studies that said an abrupt shift from a traditional setting to a technology-mediated instruction was also said to cause uncertainty and discomfort among teachers who have been used to the former (Sheriffdeen, 2007; Hardy, 2010; Géring \& Király, 2020). Thus, the administration needs to provide active support and assistance to these faculty members to ensure they are not left behind. On a positive note, younger faculty members have a low level of the perceived difficulty in implementing flexible learning strategies.

Results in Table 6 shows that faculty members with bachelor's degree have considered 2 domains to be difficult; Entry requirement $(M=3.64 ; S D=0.66)$, Content $(M=3.55 ; S D=0.79)$. Faculty members with master's degree assigned. Entry requirement $(M=3.64 ; S D=0.66)$ to be the only difficult domain, while faculty members with doctorate degree on the other hand considered 3 domains to be difficult; Entry requirement $(M=3.70 ; S D=0.67)$, Content $(M=3.68 ; S D=0.72)$, and Time $(M=3.57$; $\mathrm{SD}=0.77)$. In general, faculty members with doctorate degrees find the five domains difficult to implement $(\mathrm{M}=3.51 ; \mathrm{SD}=0.80)$. This implies that faculty members with doctorate degrees perceived the implementation of flexible learning strategies to be difficult. This can be attributed to the fact that most of them are of advanced age already and are more inclined to the traditional face-to-face classroom setting; thus, the shift to a flexible learning environment, especially an online environment, is perceived to be difficult for them (Sheriffdeen, 2007; Gillett-Swan, 2017). 
Table 6. Level of the perceived difficulty of flexible learning strategies according to educational attainment

\begin{tabular}{|c|c|c|c|c|c|c|c|c|c|}
\hline \multirow{2}{*}{ Domains } & \multicolumn{3}{|c|}{ Bachelor's Degree } & \multicolumn{3}{|c|}{ Master's Degree } & \multicolumn{3}{|c|}{ Doctorate Degree } \\
\hline & $\mathbf{M}$ & SD & Int & M & SD & Int & M & SD & Int \\
\hline Time & 3.35 & 0.75 & SD & 3.19 & 0.90 & SD & 3.57 & 0.77 & $\mathrm{D}$ \\
\hline Content & 3.55 & 0.79 & $\mathrm{D}$ & 3.27 & 0.79 & SD & 3.68 & 0.72 & $\mathrm{D}$ \\
\hline Entry Requirement & 3.64 & 0.66 & D & 3.64 & -0.87 & $D$ & 3.70 & 0.67 & $\mathrm{D}$ \\
\hline Instructional Approach \& Res. & 3.35 & 0.90 & SD & 3.26 & 0.88 & SD & 3.35 & 0.76 & SD \\
\hline Delivery and Logistics & 2.99 & 0.93 & SD & 2.92 & -0.99 & SD & 3.40 & 0.98 & SD \\
\hline As a Whole & 3.35 & 0.86 & SD & 3.20 & 0.89 & SD & 3.51 & 0.80 & $\mathrm{D}$ \\
\hline
\end{tabular}

Note: $\mathrm{VE}=$ Very Easy, $\mathrm{E}=$ Easy, $\mathrm{SD}=$ Slightly Difficult, $\mathrm{D}=$ Difficult, $\mathrm{VD}=$ Very Difficult

\section{Relationship between faculty members' demographics and perceived difficulty in flexible learning}

Spearman's rho correlation coefficient was used to assess the relationship between the faculty member's generational age, highest educational attainment, and perceived difficulty in implementing the flexible learning strategies categorized into five domains. The two-tailed test of significance revealed a significant relationship between the faculty members' generational age and their perceived difficulty in the strategies or practices Instructional Approach and Resources domain [rs $(58)=0.26, p=.04]$. This implies that the older the faculty's generational age, the higher the level of their perceived difficulty in implementing flexible learning strategies under the Instructional Approach and Resources domain. This denotes that how learning activities are carried out, e.g., face-to-face, group or in group individual, the communication and use of alternative online learning resources(Collis \& Moonen, 2002; Alder, Müller, Stahl, \& Müller, 2018)are perceived to be difficult for them. This is especially true for faculty members handling laboratory classes wherein face-toface instruction is very important for effective instruction. With the threat of COVID-19 virus faculty members also have very limited alternative options on how to carry out group works for the students considering that poor internet connectivity is a barrier for effective and responsive communication.

In addition, this finding also shows that there is a need for the faculty members to be oriented with sites offering open educational resources that could be an alternative to the traditional library materials to ensure flexibility in study materials.Collis and Moonen(2002) noted that flexibility in study materials provides wider choices to students and teachers and promotes responsibility on the part of the students to become contributory in the learning resources of the course. However, a similar two-tailed test of significance showed no significant relationship between the faculty member's generational age and their perceived difficulty in flexible learning strategies under the Time $[\mathrm{rs}(58)=0.23, p=.08]$, Content $[\mathrm{rs}(58)=0.20, p=0.12]$, Entry Requirement [rs $(58)=0.04, p=0.74]$, and Delivery and Logistics [ $r s(58)=0.15, p=.27$ ).

Moreover, Spearman's rho correlation coefficient also revealed that there was no significant correlation between the faculty member's educational attainment and their perceived difficulty in the five domains of flexible learning, Time $\left[r_{s}(58)=0.04, p=0.74\right]$, Content $\left[r_{s}(58)=-0.01, p=0.91\right]$, Entry Requirement $\left[r_{s}(58)=0.03, p=0.84\right]$, Instructional Approach and Resources domain $\left[r_{s}(58)=0.02\right.$, $p=0.89]$, and Delivery and Logistics $\left[r_{s}(58)=0.11, p=0.39\right]$.

On the other hand, a rank-Biserial correlation identified no significant relationship between the faculty member's sex and their perceived difficulty in the five domains of flexible learning Time $\left[\mathrm{r}_{\mathrm{pb}}\right.$ $(58)=-0.13, p=0.31]$, Content $\left[r_{p b}(58)=0.05, p=0.70\right]$, Entry Requirement $\left[r_{p b}(58)=-0.07, p=0.57\right]$, Instructional Approach and Resources domain $\left[r_{p b}(58)=-0.14, p=0.29\right]$, and Delivery and Logistics $\left[r_{p b}(58)=-0.14, p=0.29\right]$.

\subsection{Conclusion}

It cannot be denied that one of the core duties of an institution or a university is to capacitate its' faculty members through the provision of relevant training to make them become abreast with new trends in education amidst the COVID-19 disruption. On the part of the teachers, the continuous learning and improvement of pedagogical strategies and practices are of utmost importance, 
especially at this trying time of higher education, to ensure that the quality of education will not be compromised.

This study has shown that the university needs to focus on capacitating the faculty members to design the flexible learning course activities that are suited to students' individual backgrounds and capacities. Provision of relevant training for the faculty members on the use of applications for education or online education tools is also important, considering that most of the courses will be delivered online.

While the university battles for the idea that no student should be left behind in these trying times of education, it should also ensure that no faculty members should also be left behind. Thus, strong assistance to faculty members in advanced age should be made available by the university to ensure that everyone's needs are well supported.

\subsection{Recommendations}

In light of the findings of this study, the following recommendations are proposed:

Teachers are encouraged to update their pedagogical strategies in designing the classroom curriculum that suits the learners' individual backgrounds. One of the possible ways to do this is by attending capacity-building seminars-and workshops about the personalization of learning in the context of the learners in a flexible learning setting. The findings also suggest that teachers have to make time and exert effort in learning online educational tools or applications for delivering content and flexible assessments.

The university administration or the teacher education department heads may initiate more enhancement programs to address the teachers' need in designing a flexible classroom curriculum specifically in the personalization of learning and flexible delivery of content. The University may also ensure that technical assistance or support staff will be made available for faculty members who have difficulty doing technology-mediated instruction.

Future researchers may conduct a study on the difficulties encountered by the students in flexible learning to help the university design capacity-building programs for the students. Future researchers may also conduct a university-wide study on the level of perceived difficulty members in implementing flexible learning in other departments to find out more about the differences or similarities in the level of the perceived difficulty in the context of other higher education faculty members.

\section{REFERENCES}

Ajzen, I. (1985). From intentions to actions: a theory of planned behavior. In J. Kuhi \& J. Beckmann (Eds.), Action control: From cognition to behavior (pp. 11-39). Heidelberg:Springer.

Ajzen, I. (1991). The Theory of Planned Behavior. Organizational behavior and human decision processes, $179-211$.

Akbulev, N., Ilkin, M., \& Aliyey, V. (2020). The economic impact of COVID-19. Research Gate.

Alder, M., Müller, C., Stahl, M., \& Müller, M. (2018). Learning Effectiveness and Student's Perceptions in a Flexible Learning Course. European Journal of Open, Distance, and e-Learning, 44-52. doi:10.2478/eurodl-2018-0006

Alexander, S. (2010). Flexible Learning in Higher Education. International Encyclopedia of Education.

Arora, S. (2020). Sectoral impact of COVID-19. Research gate. doi:10.13140/RG.2.2.10121.26724

Atalan, A. (2020). Is the lockdown important to prevent the COVID-9 pandemic?: Effects on psychology, environment, and economy perspective. Annals of Medicine and Surgery. doi:https://doi.org/10.1016/j.amsu.2020.06.010

Casey, J., \& Wilson, P. (2005). A practical guide to providing flexible learning in further and higher education. Retrieved from http:// qmwww.enhancementthemes.ac.uk/docs/publications/a-practical-guide-to-providing-flexible-learning-in-further-and-highereducation.pdf

Cassidy, A., Fu, G., Valley, W., Lomas, C., \& Jovel, E. (2016). Flexible Learning Strategies in First through Fourth- Year Courses. Collected Essays on Learning and Teaching, IX, 83-94.

Cervantes, F. M. (2020). CHED pushes for flexible learning for HEIs in August. Manila: Philippine News Agency. Retrieved from https:// www.pna.gov.ph/articles/1101519

Collis, B., \& Moonen, J. (2002). Flexible Learning in a Digital World (2nd edition). Open Learning, 217-230.

Conner, M., Finlay, K., Sheeran, P., \& Trafimow, D. (2002). Evidence that perceived behavioral control is a multidimensional construct: Perceived control and perceived difficulty. British Journal of Social Psychology, 101-121.

Dorrian, J., \& Wache, D. (2008). Introduction of an online approach to flexible learning for on-campus and distance education students: Lessons learned and ways forward. Nurse Education Today, 157-167.

Elliott, S., Kratochwill, T., Littlefield, Cook, J., \& Travers, J. (2000). Educational psychology: Effective teaching, effective learning (3rd ed.). Boston: MA: McGraw-Hill College.

Géring, Z., \& Király, G. (2020). Challenges in Teaching and Learning- The Challenges of Flexible Learning. Budapest: Horizon Scanning Report Series, Volume II.

Gillett-Swan, J. (2017). The Challenges of Online Learning Supporting Engaging the Isolated Learner. Journal of Learning Design, 20-30. 
Goode, S., Willis, R., Wolf, J., \& \& Harris, A. (2007). Enhancing IS Education with Flexible Teaching and Learning. Journal of Information Systems Education, 297-302.

Hardy, I. (2010). Teacher Talk: Flexible Delivery and Academics' Praxis in an Australian University. International Journal for Academic Development, 131-142.

Herat, S. (2000). Education and Training for cleaner production: a flexible learning approach. Journal of Cleaner Production, 361-364.

Huang, R., Liu, D., Tlili, A., Yang, J., \& Wang, H. (2020). Handbook on Facilitating Flexible Learning During Educational Disruption: The Chinese Experience in Maintaining Undisrupted Learning in COVID-19 Outbreak. Beijing: Smart Learning Institute of Beijing Normal University.

Jæger, M., \& Blaabæk, E. (2020). Inequality in Learning Opportunities. Research in Social Stratification and Mobility. doi:https://doi. org/10.1016/j.rssm.2020.100524

Jansen, C., \& Merwe, P. (2015). Teaching Practice in the 21st Century: Emerging Trends, Challenges, and Opportunities. Horizon Research Publishing All.

Joan, R. (2013). Flexible Learning Design in the Classroom to Promote Quality Education. Journal on School Educational Technology

Kim, J. (2008). The perceived difficulty as a determinant of Web search performance. Information Research, 379.

Lewis, P. A., Naomi, T., Douglas, C., Gray, G., Osborne, Y. O., Evans, K., \& Nielson, C. M. (2016). Flexible learning: Evaluation of an international distance education programme designed to build the learning and teaching capacity of nurse academics in developing countries. Nurse Education in Practice.

Lewis, R., \& Spencer, D. (1986). What is Open Learning? Open Learning Guide 4. London Council for Education Technology, 9-10.

Liu, Y., Doucette, W., \& Farris, K. B. (2007). Perceived difficulty and self-efficacy in the factor structure of perceived behavioral control to seek drug information from physicians and pharmacists. Research in Social and Administrative Pharmacy.

Murakami, E., Shimizutani, S., \& Yamada, E. (2020). The potential impact of the COVID-19 pandemic on the welfare of remittancedependent households in the Philippines. CERP Press, 183-204.

National Economic and Development Authority. (2020, May 13). Home: National Economic and Development Authority. Retrieved from National Economic and Development Authority Website: http://www.neda.gov.ph/dbcc-revisits-medium-termmacroeconomic-assumptions-and-fiscal-program-amid-the-COVID-19-pandemic/

Patalla, E. A., Hooperb, S., Vasquezb, A. C., Pituchb, K. A., \& Steingutc, R. R. (2018). Science class is too hard: Perceived difficulty, disengagement, and the role of teacher autonomy support from a daily diary perspective. Learning and Instruction, 220-231.

Philippine Statistics Authority. (2020, June 5). Home: Philippine Statistics Authority. Retrieved from Philippine Statistics Authority Website: https://psa.gov.ph/statistics/survey/labor-and-employment/labor-force-survey/title/Employment\%20Situation\%20 in\%20April\%202020

Quina, Y., \& Wen, F. (2020). Who loses income during the COVID-19 outbreak? Evidence from China. Research in Social Stratification and Mobility.

Saalman, E. (2008). Flexible learning and teaching - a challenge to teachers in higher education. In Proceedings of the eighth international workshop ALE2008. Universidad Nacional, Facultad de Ingeniera, Universidad de los Andes, Bogota, Colombia.

Sheriffdeen, S. A. (2007). Challenges Faced by Staff and Students at Tertiary Level in Flexible Learning Environment. Unitec NZ.

Steeples, C., Goodyear, P., \& Mellar, H. (1994). Flexible Learning in Higher Education: The Use of Computer-Mediated Communications. Computers Educ. , 83-90.

Steepless, C., Goodyear, P., \& Mellar, H. (1994). Flexible Learning in Higher Education: The Use of Computer-MediatedCommunication. Computers Educ., 83-90.

Toquero, C. M. (2020). Challenges and Opportunities for Higher Education amid the COVID-19 Pandemic: The Philippine Context. Pedagogical Research. doi:https://doi.org/10.29333/pr/7947

UNESCO. (2020). Home: UNESCO. Retrieved from UNESCO Website: https://en.unesco.org/COVID-19/educationresponse

UNESCO. (2020, April). News: UNESCO Web Page. Retrieved from UNESCO Web site: https://en.unesco.org/news/frameworkreopening-schools

\section{Correspondence:}

KEVIN T. LAGAT

kevlagat05@gmail.com

https://orcid.org/0000-0002-1272-5653 